\title{
Kiegészítóanyagok hatása
}

\section{a szokványos és az öntömörödó betonokra \\ 2. rész. Laboratóriumi vizsgálatok}

Salem Georges NEHME • egyetemi docens, BME Építôanyagok és Magasépítés Tanszék - sgnehme@yahoo.com

Érkezett: 2015. 02. 22. - Received: 22. 02. 2015. - http://dx.doi.org/10.14382/epitoanyag-jsbcm.2015.12
Salem Georges NEHME Okleveles épitổmérnök, PhD, egyetemi docens a BME Épitőanyagok és Magasépités Tanszékén. A Magyar Szabványügyi Testület MSZT/MB 112 Építési üveg nemzeti szabványosító müszak bizottság tagja; a fib Magyar Tagozat tagja; a Magyar Mérnöki Kamara tagja (MMK: 01 9159). Érdeklödési területei: betontechnológia, tömegbetonok, öntömörödố betonok szálerốsitésú betonok, minőségellenổrzés, roncsolásmentes anyagvizsgálatok, vasbeton szerkezetek, épitő̃anyagok újrahasznositása.

\section{Influence of supplementary cementing materials on conventional and self compacting concretes}

\section{Part. 2. Laboratory tests}

The use of supplementary cementing materials in concrete technology may help reducing the large carbon-dioxide emission that is resulted from the production of Portland cements. The supplementary cementing materials can be classified as hydraulic additives, pozzolanic additives and inert additives. The supplementary cementing materials form calcium-silicate-hydrates and calcium-aluminate-hydrates with the calcium hydroxide available due to Portland cement hydration. Most active supplementary cementing materials are the silica fume and the metakaolin. The literature indicates that the application of silica fume or metakaolin improves the durability of concrete due to the finer pore microstructure that results lower porosity, lower permeability, higher strength, higher resistance against water penetration and higher resistance to acidic solutions. The present paper is the first part of a series of papers dealing with conventional and self compacting concretes containing silica fume or the metakaolin supplementary cementing materials. The first part gives a literature review of the supplementary cementing materials tested. The second part summarizes own experimental results.

Keywords: concrete, self compacting concrete, supplementary cementing materials, metakaolin, silica fume

Kulcsszavak: beton, öntömörödố beton, kiegészítőanyagok, metakaolin, szilikapor

\section{Előzmények}

Cikksorozatunk első részében összefoglaltuk a kapcsolódó szakirodalmi adatokat. Jelen cikk a saját kísérleti eredményeket ismerteti.

\section{Kísérleti terv}

A kísérlet célja a szilikapor, a metakaolin és a mészkőliszt adagolás hatásának elemzése a szokványos és öntömörödő betonokra, mind a frissbetonra, mind a megszilárdult betonra.

A kísérletek során 39 különböző receptúrát használtunk, ezeket az 1. táblázatban foglaljuk össze. A keverések fele szokványos, fele öntömörödő beton volt. A 18-18 keverést hármas csoportokra bontva készültek etalonok, szilikaport és metakaolint tartalmazó próbatestek.

A vizsgálatok során a következő állandó paramétereket alkalmaztuk:

- az adalékanyag szemmegoszlása,

- az adagolt víz mennyisége $\left(180 \mathrm{l} / \mathrm{m}^{3}\right)$,

- a cement típusa,

- $10 \mathrm{~m} \%$ szilikapor és metakaolin.

A kísérletek változó paraméterei:

- a cement mennyisége $(300,320,340,360,380,400$ és $\left.420 \mathrm{~kg} / \mathrm{m}^{3}\right)$,

- az adagolt szilikapor és metakaolin mennyisége (a cementtartalom tömegének függvényében $30,32,36,38$, 40 és $42 \mathrm{~kg} / \mathrm{m}^{3}$ ),

- a víz-cement tényezö $(0,60$ - 0,56 - 0,53 - 0,50 - 0,47 - 0,45 - 0,429).
A kísérletekhez hét eltérő cementtartalmú receptúrát vettünk alapul. A kísérletek célja:

- A különböző cementtartalmú, de állandó víztartalmú szokványos és öntömörödő betonok esetén, hogyan változnak a friss és a megszilárdult betonok tulajdonságai metakaolin és szilikapor adagolása esetén a nagy fajlagos felületük miatt.

- Összehasonlítani a metakaolin hatását a szilikapor hatásához.

Az irodalom alapján a cement tömegére vonatkoztatott 10\%os adagolás mellett vizsgáltuk a szilikapor és a metakaolin hatását.

\section{Kísérleti paraméterek}

\subsection{A kísérlet során felhasznált anyagok}

\subsubsection{Adalékanyag}

Az alkalmazott adalékanyag homokos kavics volt (TBG, Basa utcai telep). A keverési arányokat a 2. táblázat tartalmazza.

A maximális szemnagyság $d_{\max }=16 \mathrm{~mm}$ volt. Felhasználás elött a kavicsot levegőn, a homokot pedig szárítószekrényben szárítottuk.

\subsubsection{Kiegészítőanyagok}

\subsubsection{Szilikapor}

Sika Silicoll $\mathrm{P}$ gyártmányú szilikaport használtunk a keverésekhez. A gyártótól származó adatokat a 3. táblázat tartalmazza (Sika, 2015). 


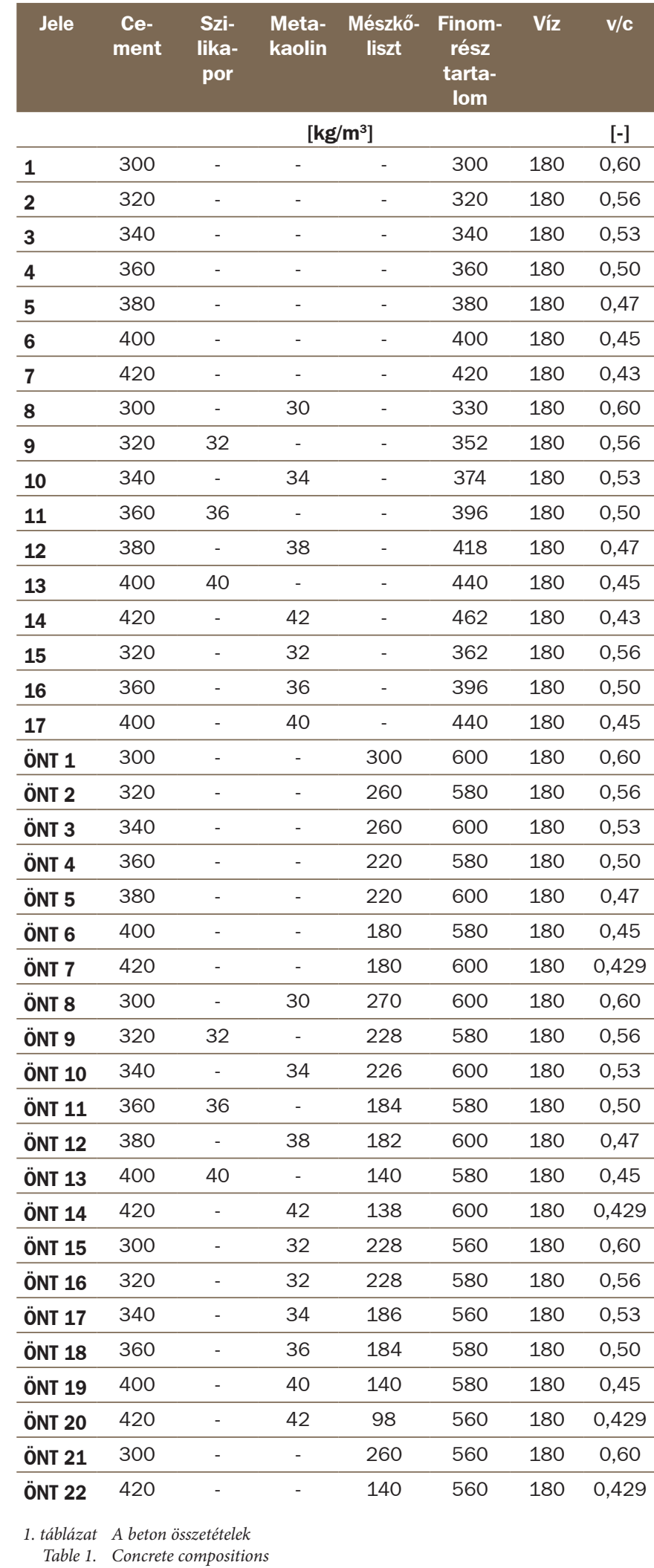

\begin{tabular}{cc}
$\begin{array}{c}\text { Frakció } \\
\mathbf{m m}\end{array}$ & $\begin{array}{c}\text { Keverési arány } \\
\%\end{array}$ \\
\hline $0 / 4$ & 45 \\
\hline $4 / 8$ & 25 \\
\hline $8 / 16$ & 30
\end{tabular}

2. táblázat Adalékanyagok keverési arányai Table 2. Mixing ratio of aggregatefractions

\subsubsection{Metakaolin}

Metaver $^{\circledast} \mathrm{N}$ típusú metakaolint használtunk a keverések során. A gyártó által megadott jellemzőket a 4. táblázat tartalmazza (Newchem, 2015).

\subsubsection{Mészkőliszt}

$\mathrm{Az}$ öntömörödő betonhoz a Carmeuse által előállított mészkőlisztet használtunk. A mészkőliszt fajlagos felületét és sürüségét az 5. táblázatban foglaltuk össze.

\subsubsection{Adalékszer}

A BASF által gyártott polikarboxilát éter bázisú Glenium ${ }^{\circledast} 51$ jelü szuperfolyósítót használtuk a keverések során.

\section{Vizsgálatok és eredmények}

\subsection{A frissbeton tulajdonságai}

A konzisztencia meghatározását elsősorban terülésméréssel hajtottuk végre (6. táblázat).

A hagyományos betonok esetében a mérést az MSZ EN 12350-5:2009 szabvány alapján végeztük. Minden esetben két, egymásra meröleges mérés átlaga adta a mért értéket. A méreteket $0,5 \mathrm{~cm}$ pontossággal állapítottuk meg.

Az öntömörödö betonok roskadási terülését a kifolyási időt vizsgáltuk és az eredményeket a 6. táblázatban foglaltuk össze. Ellenőriztük a friss beton testsűrüségét is.

\subsection{Nyomószilárdsági vizsgálatok}

Az MSZ EN 12390-3:2009 szabványnak megfelelően a vizsgálat elvégzéséhez FORM+TEST gyártmányú ALPHA-3-3000 $\mathrm{S}$ jelü, $3000 \mathrm{kN}$ maximális terhelésü, erővezérelt berendezést használtunk.

Keverésenként 3-3 darab 150 mm élhosszúságú próbakockát 1, 2, 7 és 28 napos korban törtünk el. A törőerőkből számított nyomószilárdságot a 7. táblázat tartalmazza.

\begin{tabular}{|c|c|c|}
\hline \multicolumn{3}{|c|}{ Sika Silicoll P } \\
\hline $\mathrm{SiO}_{2}$ tartalom & $96 \pm 1,5$ & $\%$ \\
\hline Elsôdleges szemnagyság & $0,1-0,3$ & $\mu \mathrm{m}$ \\
\hline Másodlagos részecskék ( > 1 mm) & 30 & $\%$ \\
\hline
\end{tabular}

\begin{tabular}{ccc}
\multicolumn{3}{c}{ Fö kémiai összetevők } \\
$\mathrm{SiO}_{2}$ & $52-53$ & $\%$ \\
\hline $\mathrm{Al}_{2} \mathrm{O}_{3}$ & $43-44$ & $\%$ \\
\hline Tijpikus szemcseeloszlás (lézergranulométer) & \\
\hline$<1 \mathrm{~mm}$ & $7-9$ & V\% \\
\hline $\mathrm{d}_{50}$ & $3,4-4,5$ & $\mu \mathrm{m}$ \\
\hline $\mathrm{d}_{95}$ & $12-18$ & $\mu \mathrm{m}$ \\
\hline $\begin{array}{l}\text { 4. táblázat } \\
\text { Table 4. }\end{array}$ & $\begin{array}{l}\text { Metakaolin tulajdonságai } \\
\text { Properties of metakaolin }\end{array}$ & \\
\end{tabular}

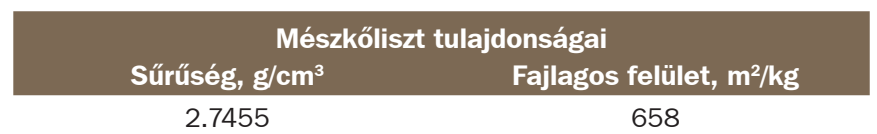

5. táblázat Mészkőliszt sürüsége és fajlagos felülete

Table 5. Density and specificsurfacearea of limestonepowder 


\begin{tabular}{|c|c|c|c|c|c|c|c|c|c|}
\hline Jele & Cement & Szilikapor & $\begin{array}{l}\text { Meta- } \\
\text { kaolin }\end{array}$ & $\begin{array}{l}\text { Mészkő- } \\
\text { liszt }\end{array}$ & $\begin{array}{c}\text { Finomrész } \\
\text { tartalom }\end{array}$ & Víz & $v / c$ & Terülés & $\begin{array}{l}\text { Friss beton } \\
\text { testsúrúség }\end{array}$ \\
\hline & \multicolumn{6}{|c|}{$\mathrm{kg} / \mathrm{m}^{3}$} & {$[-]$} & $\mathbf{m m}$ & $\mathrm{kg} / \mathrm{m}^{3}$ \\
\hline 1 & 300 & - & - & - & 300 & 180 & 0,60 & 575 & 2326 \\
\hline 2 & 320 & - & - & - & 320 & 180 & 0,56 & 570 & 2363 \\
\hline 3 & 340 & - & - & - & 340 & 180 & 0,53 & 505 & 2283 \\
\hline 4 & 360 & - & - & - & 360 & 180 & 0,50 & 570 & 2371 \\
\hline 5 & 380 & - & - & - & 380 & 180 & 0,47 & 565 & 2359 \\
\hline 6 & 400 & - & - & - & 400 & 180 & 0,45 & 540 & 2362 \\
\hline 7 & 420 & - & - & - & 420 & 180 & 0,43 & 570 & 2321 \\
\hline 8 & 300 & - & 30 & - & 330 & 180 & 0,60 & 580 & 2344 \\
\hline 9 & 320 & 32 & - & - & 352 & 180 & 0,56 & 525 & 2355 \\
\hline 10 & 340 & - & 34 & - & 374 & 180 & 0,53 & 525 & 2291 \\
\hline 11 & 360 & 36 & - & - & 396 & 180 & 0,50 & 540 & 2345 \\
\hline 12 & 380 & - & 38 & - & 418 & 180 & 0,47 & 510 & 2282 \\
\hline 13 & 400 & 40 & - & - & 440 & 180 & 0,45 & 520 & 2351 \\
\hline 14 & 420 & - & 42 & - & 462 & 180 & 0,43 & 590 & 2323 \\
\hline 15 & 320 & - & 32 & - & 362 & 180 & 0,56 & 550 & 2365 \\
\hline 16 & 360 & - & 36 & - & 396 & 180 & 0,50 & 545 & 2357 \\
\hline 17 & 400 & - & 40 & - & 440 & 180 & 0,45 & 530 & 2376 \\
\hline ÖNT 1 & 300 & - & - & 300 & 600 & 180 & 0,60 & 750 & 2310 \\
\hline ÖNT 2 & 320 & - & - & 260 & 580 & 180 & 0,56 & 710 & 2374 \\
\hline ÖNT 3 & 340 & - & - & 260 & 600 & 180 & 0,53 & 705 & 2383 \\
\hline ÖNT 4 & 360 & - & - & 220 & 580 & 180 & 0,50 & 750 & 2383 \\
\hline ÖNT 5 & 380 & - & - & 220 & 600 & 180 & 0,47 & 670 & 2354 \\
\hline ÖNT 6 & 400 & - & - & 180 & 580 & 180 & 0,45 & 760 & 2397 \\
\hline ÖNT 7 & 420 & - & - & 180 & 600 & 180 & 0,429 & 780 & 2321 \\
\hline ÖNT 8 & 300 & - & 30 & 270 & 600 & 180 & 0,60 & 745 & 2316 \\
\hline ÖNT 9 & 320 & 32 & - & 228 & 580 & 180 & 0,56 & 600 & 2365 \\
\hline ÖNT 10 & 340 & - & 34 & 226 & 600 & 180 & 0,53 & 705 & 2437 \\
\hline ÖNT 11 & 360 & 36 & - & 184 & 580 & 180 & 0,50 & 740 & 2376 \\
\hline ÖNT 12 & 380 & - & 38 & 182 & 600 & 180 & 0,47 & 750 & 2335 \\
\hline ÖNT 13 & 400 & 40 & - & 140 & 580 & 180 & 0,45 & 715 & 2390 \\
\hline ÖNT 14 & 420 & - & 42 & 138 & 600 & 180 & 0,429 & 740 & 2349 \\
\hline ÖNT 15 & 300 & - & 32 & 228 & 560 & 180 & 0,60 & 620 & 2337 \\
\hline ÖNT 16 & 320 & - & 32 & 228 & 580 & 180 & 0,56 & 675 & 2370 \\
\hline ÖNT 17 & 340 & - & 34 & 186 & 560 & 180 & 0,53 & 760 & 2334 \\
\hline ÖNT 18 & 360 & - & 36 & 184 & 580 & 180 & 0,50 & 745 & 2397 \\
\hline ÖNT 19 & 400 & - & 40 & 140 & 580 & 180 & 0,45 & 770 & 2356 \\
\hline ÖNT 20 & 420 & - & 42 & 98 & 560 & 180 & 0,429 & 700 & 2339 \\
\hline ÖNT 21 & 300 & - & - & 260 & 560 & 180 & 0,60 & 770 & 2326 \\
\hline ÖNT 22 & 420 & - & - & 140 & 560 & 180 & 0,429 & 755 & 2317 \\
\hline
\end{tabular}

6. táblázat A terülésmérés eredményei

Table 6. Results of flow table tests 


\begin{tabular}{|c|c|c|c|c|c|c|c|c|c|c|c|c|}
\hline \multirow{2}{*}{ Jele } & \multirow{2}{*}{$\begin{array}{l}v / c \\
{[-]} \\
\end{array}$} & \multicolumn{4}{|c|}{ Nyomószilárdság, N/mm² } & \multirow{3}{*}{ Jele } & \multirow{3}{*}{ Cement } & \multirow{3}{*}{$v / c$} & \multirow{3}{*}{$\begin{array}{l}\text { Friss- } \\
\text { beton } \\
\text { testsú- } \\
\text { rüsége }\end{array}$} & \multirow{3}{*}{$\begin{array}{l}\text { Beton test- } \\
\text { sürüsége } \\
28 \text { napos } \\
\text { korban }\end{array}$} & \multirow{3}{*}{$\begin{array}{l}\text { Átlagos } \\
\text { vízbe- } \\
\text { hatolási } \\
\text { mélység }\end{array}$} & \multirow{3}{*}{$\begin{array}{c}\text { Kör- } \\
\text { nyezeti } \\
\text { osztály }\end{array}$} \\
\hline & & 1 & 2 & 7 & 28 & & & & & & & \\
\hline 1 & 0,60 & 4,34 & - & 28,1 & 44,8 & & & & & & & \\
\hline 2 & 0,56 & - & 14,6 & 28,1 & 45,4 & & {$\left[\mathrm{~kg} / \mathrm{m}^{3}\right]$} & {$[-]$} & {$\left[\mathrm{kg} / \mathrm{m}^{3}\right]$} & {$\left[\mathrm{kg} / \mathrm{m}^{3}\right]$} & {$[\mathrm{mm}]$} & \\
\hline 3 & 0,53 & 6,67 & - & 28,7 & 47,8 & 1 & 300 & 0,60 & 2326 & 2284 & 28,4 & XV2 $(H)$ \\
\hline 4 & 0,50 & - & 19,5 & 36,6 & 48,9 & 2 & 320 & 0,56 & 2363 & 2324 & 24,2 & XV2 (H) \\
\hline 5 & 0,47 & 7,21 & - & 37,9 & 52,6 & 3 & 340 & 0,53 & 2283 & 2294 & 21,9 & XV2 (H) \\
\hline 6 & 0,45 & - & 22,2 & 41,4 & 53,5 & 4 & 360 & 0,50 & 2371 & 2340 & 16 & XV3 (H) \\
\hline 7 & 0,43 & 10,53 & - & 42,1 & 65,1 & 5 & 380 & 0,47 & 2359 & 2332 & 15,4 & XV3 (H) \\
\hline 8 & 0,60 & 6,71 & - & 34,1 & 57.7 & 6 & 400 & 0,45 & 2362 & 2337 & 14,5 & XV3 (H) \\
\hline 9 & 0,56 & - & 17,3 & 40,4 & 608 & 7 & 420 & 0,43 & 2321 & 2298 & 14,1 & XV3 $(\mathrm{H})$ \\
\hline & & & & & & 8 & 300 & 0,60 & 2344 & 2312 & 15,1 & XV3 $(H)$ \\
\hline 10 & 0,53 & 6,71 & - & 35,9 & 66,7 & 9 & 320 & 0,56 & 2355 & 2345 & 11 & XV3 $(H)$ \\
\hline 11 & 0,50 & - & 23,8 & 47,7 & 70,2 & 10 & 340 & 0,53 & 2291 & 2313 & 8,9 & XV3 (H) \\
\hline 12 & 0,47 & 7,68 & - & 49,7 & 70,1 & 11 & 360 & 0,50 & 2345 & 2347 & 5 & XV3 $(H)$ \\
\hline 13 & 0,45 & - & 25,2 & 50,0 & 71,9 & 12 & 380 & 0,47 & 2282 & 2274 & 8,75 & XV3 $(H)$ \\
\hline 14 & 0,43 & 8,96 & - & 51,9 & 77,2 & 13 & 400 & 0,45 & 2351 & 2334 & 8 & XV3 (H) \\
\hline 15 & 0,56 & - & 16,1 & 34,3 & 56,5 & 14 & 420 & 0,43 & 2323 & 2316 & 8,9 & XV3 $(H)$ \\
\hline 16 & 0,50 & - & 25,8 & 46,2 & 68,4 & 15 & 320 & 0,56 & 2365 & 2339 & 10 & XV3 $(H)$ \\
\hline 17 & 0,45 & - & 29,9 & 51,2 & 73,3 & 16 & 360 & 0,50 & 2357 & 2328 & 5,5 & XV3 $(H)$ \\
\hline ÖNT 1 & 0,60 & 7,01 & - & 31,3 & 51,8 & 17 & 400 & 0,45 & 2376 & 2352 & 9,6 & XV3 $(H)$ \\
\hline ÖNT 2 & 0,56 & 6,3 & 20,4 & 36,9 & 49,7 & ÖNT 1 & 300 & 0,60 & 2310 & 2290 & 18,8 & XV3 $(H)$ \\
\hline ÖNT 3 & 0,53 & 7,8 & - & 37,4 & 56,5 & ÖNT 2 & 320 & 0,56 & 2374 & 2333 & 16 & XV3 $(H)$ \\
\hline ÖNT 4 & 0,50 & 7,2 & 26,8 & 45,9 & 59,4 & ÖNT 3 & 340 & 0,53 & 2383 & 2262 & 15,4 & XV3 $(H)$ \\
\hline ÖNT 5 & 0,47 & 9,3 & - & 44,6 & 67,2 & ÖNT 4 & 360 & 0,50 & 2383 & 2351 & 15 & XV3 $(H)$ \\
\hline ÖNT 6 & 0,45 & 5,4 & 29,8 & 47,5 & 67,7 & ÖNT 5 & 380 & 0,47 & 2354 & 2303 & 9,3 & XV3 (H) \\
\hline ÖNT 7 & 0,429 & 14,71 & - & 49,7 & 75,7 & ÖNT 6 & 400 & 0,45 & 2397 & 2371 & 9 & XV3 $(H)$ \\
\hline ÖNT 8 & 0,60 & 10,61 & - & 40,1 & 64,0 & ÖNT 7 & 420 & 0,429 & 2321 & 2298 & 7,5 & XV3 (H) \\
\hline ÖNT 9 & 0,56 & 5,6 & 23,9 & 43,2 & 66,5 & ÖNT 8 & 300 & 0,60 & 2316 & 2298 & 10,7 & XV3 $(H)$ \\
\hline ÖNT 10 & 0,53 & 13,93 & - & 43,0 & 70,5 & ÖNT 9 & 320 & 0,56 & 2365 & 2356 & 14,2 & XV3 $(H)$ \\
\hline ÖNT 11 & 0,50 & 5,4 & 28,3 & 51,0 & 77,3 & ONT 10 & 340 & 0,53 & 2437 & 2311 & 6,2 & XV3 (H) \\
\hline ÖNT 12 & 0,47 & 16,47 & - & 46,6 & 78,1 & ONT 11 & 360 & 0,50 & 2376 & 2353 & 9 & $\mathrm{XV} 3(\mathrm{H})$ \\
\hline ÖNT 13 & 0,45 & 5,5 & 34,3 & 57,0 & 83,3 & ONT 12 & 380 & 0,47 & 2335 & 2317 & 6,4 & XV3 $(H)$ \\
\hline ÖNT 14 & 0,429 & 16,86 & - & 52,4 & 81,0 & ONT 13 & 400 & 0,45 & 2390 & 2376 & 6 & XV3 $(H)$ \\
\hline ÖNT 15 & 0,60 & 11,36 & - & 473 & 630 & ONT 14 & 420 & 0,429 & 2349 & 2311 & 6,6 & XV3 (H) \\
\hline ÖNT 16 & 0,56 & 7,6 & 26,0 & 449 & 69.0 & ONT 15 & 300 & 0,60 & 2337 & 2290 & 8,1 & XV3 (H) \\
\hline ÖNT 17 & 0,53 & 11,64 & - & 531 & 71.1 & ONT 16 & 320 & 0,56 & 2310 & 2342 & 10 & $X \vee 3(H)$ \\
\hline ÖNT 18 & 0,50 & 6,4 & 31,8 & 530 & 784 & ONT 17 & 340 & 0,53 & 2334 & 2316 & 7,6 & $x \vee 3(H)$ \\
\hline ÖNT 19 & 0,45 & 6,2 & 27,4 & 54,2 & 79,2 & ÖNT 19 & 400 & 0.45 & 2356 & 2363 & $\gamma$ & $x \vee s(H)$ \\
\hline ÖNT 20 & 0,429 & 15,96 & - & 62,2 & 84,5 & ÖNT 20 & 420 & 0,429 & 2339 & 2309 & 5,2 & XV3 (H) \\
\hline ÖNT 21 & 0,60 & 11,93 & - & 39,3 & 53,6 & ÖNT 21 & 300 & 0,60 & 2326 & 2331 & 15,8 & XV3 (H) \\
\hline ÖNT 22 & 0,429 & 14,9 & - & 53,8 & 69,6 & ÖNT 22 & 420 & 0,43 & 2317 & 2321 & 9,9 & XV3 (H) \\
\hline $\begin{array}{l}\text { 7. táblázat } \\
\text { Table } 7 .\end{array}$ & $\begin{array}{l}\text { omószilár } \\
\text { mpressive }\end{array}$ & $\begin{array}{l}\text { eredmények } \\
\text { gth results }\end{array}$ & & & & $\begin{array}{l}\text { 8. táblázat } \\
\text { Table } 8 .\end{array}$ & $\begin{array}{l}\text { Vizzárósá } \\
\text { Watertigh }\end{array}$ & $\begin{array}{l}\text { eredmények } \\
\text { zess results }\end{array}$ & & & & \\
\hline
\end{tabular}




\subsection{Vízzárósági vizsgálatok}

A vízzárósági vizsgálatot az MSZ EN 12390-8:2009 szabvány alapján WE $6 \mathrm{MM}$ jelü készülékkel hajtottuk végre. Receptúránként 3-3db 150 cm élhosszúságú kockát tartottunk 72 óráig a berendezésben. A víznyomás a kísérlet ideje alatt végig 5 bar volt. A vizsgálati eredményeket a 8 . táblázatban foglaltuk össze.

\section{Kísérleti eredmények értékelése}

\subsection{A nyomószilárdsági vizsgálat eredményeinek értékelése}

A kísérlet során kapott szilárdsági eredményeket részletesen a 7. táblázat tartalmazza.

A nyomószilárdsági vizsgálatokat 1, 2, 7 és 28 napos korban végeztük el 3-3 próbatesten.

\subsubsection{A szokványos betonok nyomószilárdsága}

Az 1. ábra mutatja az egyes keverékek szilárdságának alakulását. A hozzáadott víz mennyisége állandó volt, így a cementtartalom növekedésével csökkent a víz-cement tényező, ami a szilárdságnövekedést okozhatta.

A metakaolin és a szilikapor nyomószilárdság növelő hatása jól megfigyelhető állandó víz-cement tényező esetén, de a metakaolin tartalmú és a szilikapor tartalmú összetételek közti nyomószilárdság különbségét nem tapasztaltuk. Állandó víztartalom mellett a $10 \%$ metakaolin és szilikapor adagolással nagyobb nyomószilárdságot értünk el, mint többlet $10 \%$ cement adagolással.

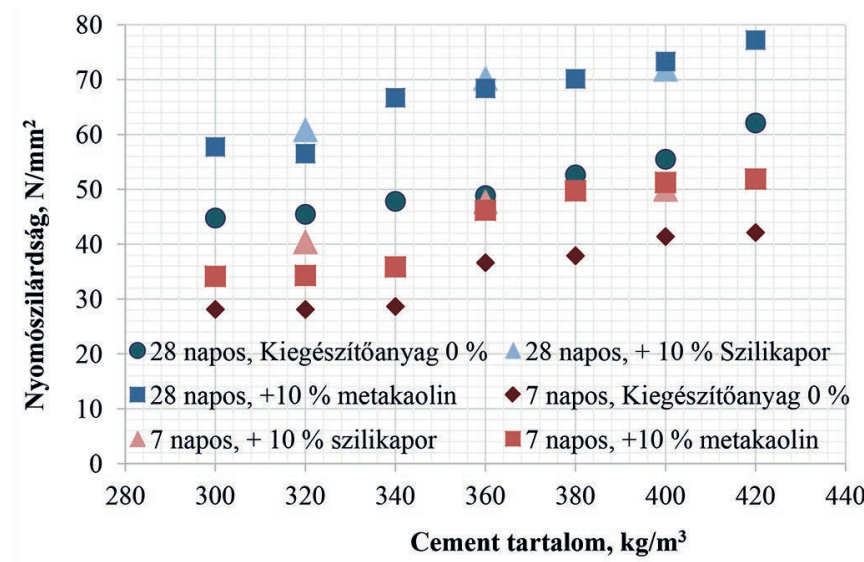

\footnotetext{
1. ábra Szokványos betonok nyomószilárdsága cementtartalom függvényében állandó víz-cement tényezö mellett

Fig. 1. Compressive strength of conventional concretes in the function of cement content
}

Az 1. ábrán megfigyelhetjük, hogy a nagyobb víz-cement tényező esetén a metakaolin és a szilikapor nagyobb mértékben fejti ki hatását. Víz jelenlétében a metakaolin vagy a szilikapor és a cement hidratációjából keletkező kalcium-hidroxid reakcióba lép, melynek eredménye kalcium-szilikát-hidrát (CSH). A nagyobb v/c tényezővel rendelkező receptúra esetén több víz párolog el, ami után nagyobb kapillárisok maradnak a beton mikrostruktúrájában, ahol könnyebben végbemegy ez a reakció.

\subsubsection{Az öntömörödő betonok nyomószilárdsága}

A 2. és 3. ábra mutatja az egyes keverékek szilárdságának alakulását 7 napos és 28 napos korban. Az öntömörödő betonoknál is hasonlóan alakult a hőmérséklet, mint a szokványos betonoknál. A hozzáadott víz mennyisége állandó volt, így a cementtartalom növekedésével csökkent a víz-cement tényező, ami a szilárdságnövekedést okozhatta.

A metakaolin és a szilikapor nyomószilárdság növelő hatása itt is jól megfigyelhető állandó víz-cement tényező esetén. A metakaolin tartalmú és a szilikapor tartalmú összetételek között nyomószilárdság különbséget nem tapasztaltunk.

A 2. ábrán és 3. ábrán is megfigyelhetjük, hogy a nagyobb víz-cement tényező esetén a metakaolin és a szilikapor nagyobb mértékben fejti ki hatását. Továbbá a kisebb víz-cement tényező és nagyobb finomrész-tartalom $(600 \mathrm{~kg})$ esetén kisebb a metakaolin hatása a nyomószilárdságra. A megállapítások 28 napos korra vonatkoznak.

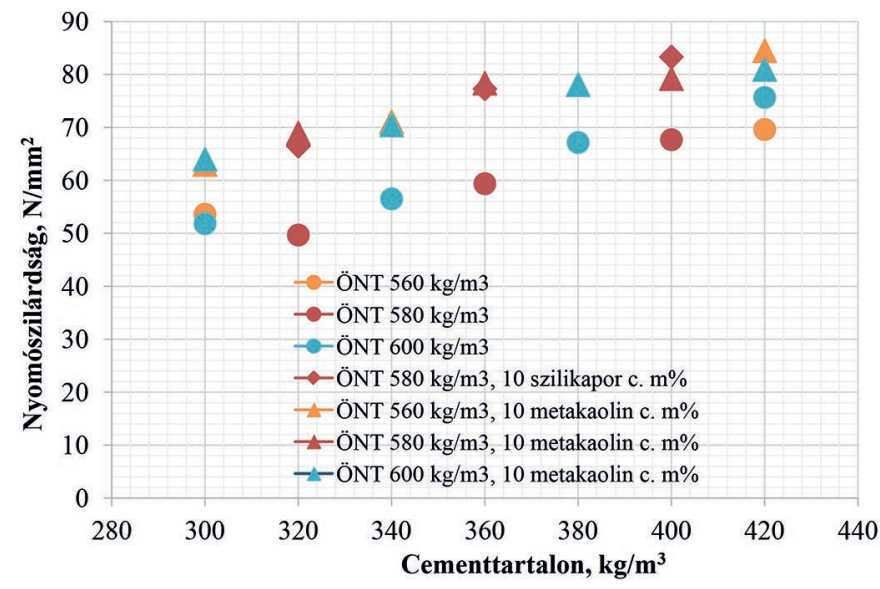

2. ábra A öntömörödö betonok nyomószilárdsága cementtartalom függvényében állandó viztartalom mellett 28 napos korban

Fig. 2. Compressive strength of self compacting concretes in the function of cement content (water content constant; 28 days of age)

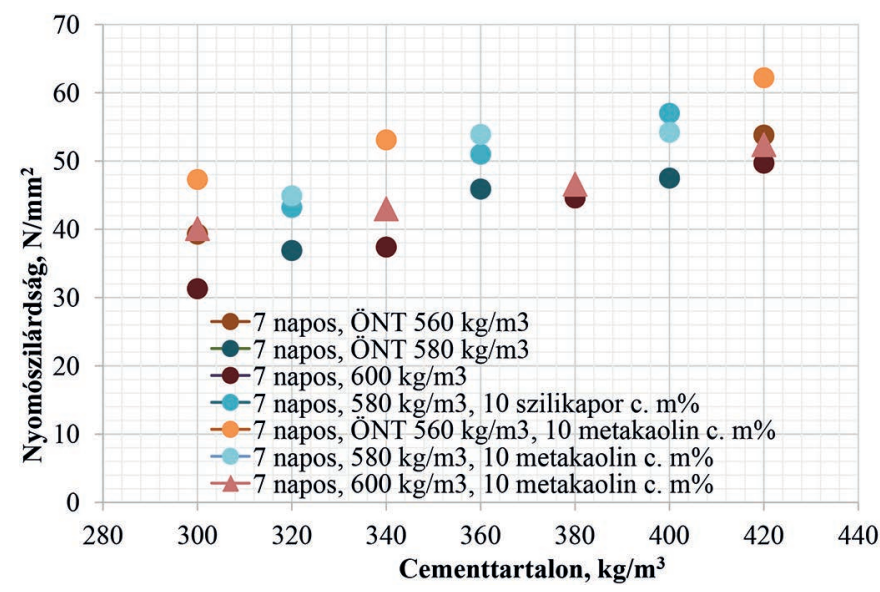

3. ábra A öntömörödö betonok nyomószilárdsága cementtartalom függvényében állandó viztartalom mellett 7 napos korban

Fig. 3. Compressive strength of self compacting concretes in the function of cement content (water content constant; 7 days of age) 


\subsection{A vízzárósági vizsgálat eredményeinek értékelése}

Minden keverés esetén végeztünk vízzárósági vizsgálatot is. Keverésenként 3-3 próbatestet vizsgáltunk, a vízbehatolás mértékét a három mérés átlaga adta.

Szokványos betonok esetén, a kísérletek alapján a vízbehatolásra vonatkozó, XV3 $(\mathrm{H})$ osztályhoz tartozó max. $20 \mathrm{~mm}$ elöírást kivétel nélkül mindegyik próbatest teljesítette, ahol a víz-cement tényező kisebb volt, mint 0,53. Ahol szilikaport vagy metakaolint adagoltunk, ott mindegyik próbatest teljesítette az XV3 (H) osztályt (lásd 4. ábra). Ezzel szemben, ha a szabvány által előírt paraméterek alapján vizsgáltuk a betonokat, egy vagy akár két osztállyal is gyengébb kategóriába kerültek. Érdemes megfigyelni, hogy a gyengébb osztályba sorolás oka az esetek kb. 70 \%-ban az volt, hogy a betonok nem feleltek meg a testsürüségre elöírt követelményeknek. Az eredmények alapján tehát jogos az elöírások újragondolása, a testsürüségre elöírt feltételek változtatása vagy akár törlése a szabványból.

Öntömörödő betonok esetén, a kísérletek alapján a vízbehatolásra vonatkozó, XV3 $(\mathrm{H})$ osztályhoz tartozó max. $20 \mathrm{~mm}$ előírást kivétel nélkül mindegyik próbatest teljesítette. Ahol szilikaport vagy metakaolint adagoltunk, ott mindegyik próbatest teljesítette az XV3 (H) osztályt és a vízbehatolás különbségek mértéke elhanyagolható volt (lásd 5. ábra).

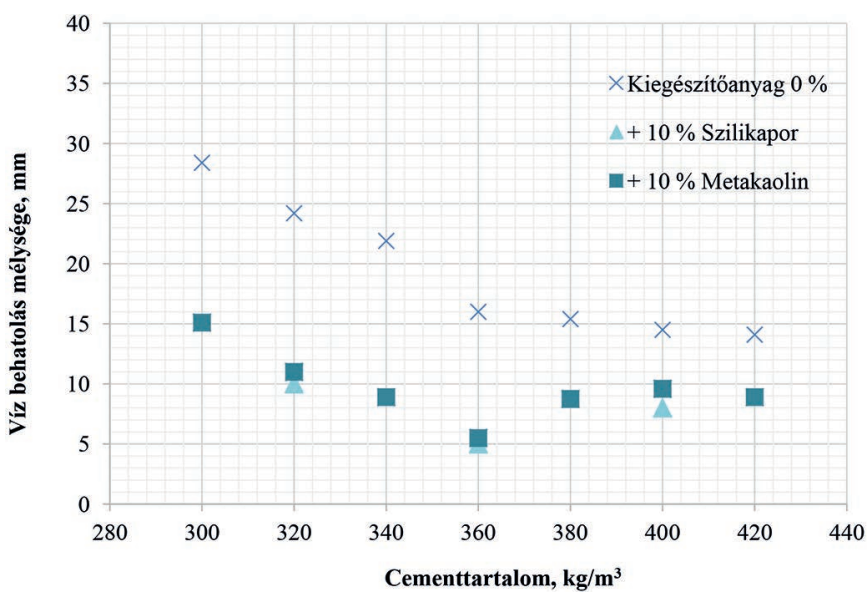

\footnotetext{
4. ábra A szokványos betonok vízbehatolása cementtartalom függvényében állandó viztartalom mellett

Fig. 4. Water penetration into conventional concretes (water content constant)
}

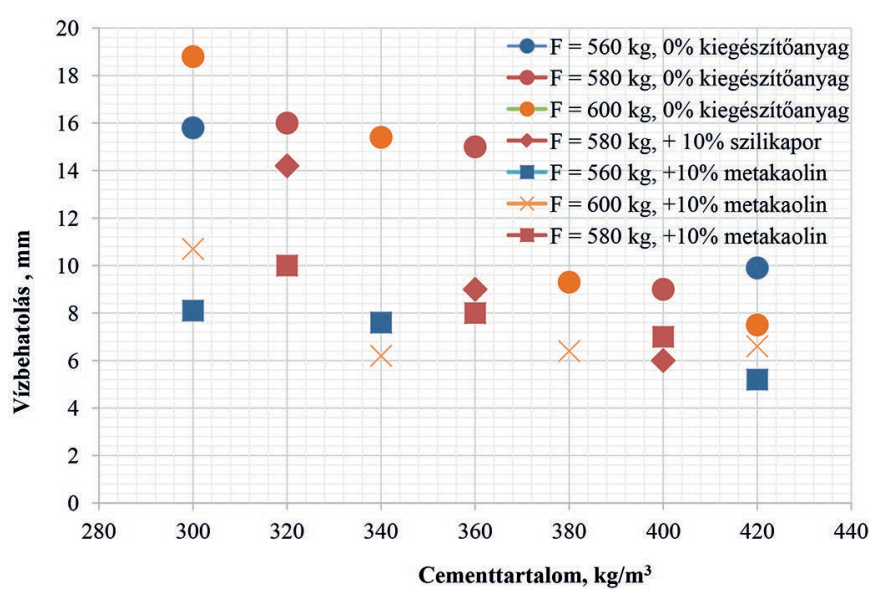

5. ábra Az öntömörödö betonok vízbehatolása cementtartalom függvényében állandó víztartalom mellett

Fig. 5. Water penetration into self compacting concretes (water content constant)

\section{6. Összefoglalás}

Összesen 39 különböző keveréket készítettünk.

A kísérletek során alkalmazott összetételekben a következő állandó és változó paramétereink voltak:

Állandó paraméterek:

- szemeloszlási görbe,

- cement fajta,

- víz adagolás: $180 \mathrm{l} / \mathrm{m}^{3}$,

- metakaolin vagy szilikapor adagolása $10 \%$.

Változó paraméterek:

- cement mennyiség 300, 320, 340, 360, 380, 400, $420 \mathrm{~kg} / \mathrm{m}^{3}$ és az által a v/c tényezö,

- öntömörödő betonok esetén mészkőliszt adagolás és finomrész-tartalom.

A következő megállapítások tehetők a fent említett paraméterek függvényében:

Nyomószilárdságra vonatkozóan:

- A cement tömegére vonatkoztatott 10 m\%-os mennyiségében történő metakaolin vagy szilikapor adagolás mellett a szokványos és öntömörödő betonok esetében a nyomószilárdság átlagosan 15-30\%-kal nő. Állandó víz mennyiség mellett a $10 \mathrm{~m} \%$ metakaolin vagy szilikapor adagolás esetén nagyobb szilárdság növekedést értünk el, mint 10 \% többlet cement adagolással.

- Nagyobb víz-cement tényező esetén nagyobb hatást értünk el a metakaolin vagy szilikapor adagolással a kis víz-cement tényezőhöz képest. Víz jelenlétében a metakaolin vagy a szilikapor és a cement hidratációjából keletkező kalcium-hidroxid reakcióba lép, melynek eredménye kalcium-szilikát-hidrát (CSH).

- Metakaolin vagy szilikapor adagolása közötti nyomószilárdság különbséget nem észleltünk 28 napos korban.

- A finomrész tartalom változtatása során azt állapítottuk meg, hogy egy adott mészkőliszt adagolás túllépése szilárdságcsökkenéshez vezet.

- Az öntömörödő betonok esetében a szilikapor és a metakaolin azonos adagolása a normál betonokhoz képest jobban kifejtette a hatását. A normál beton esetén a k érték felülről közelíti a 2-őt, míg az öntömörödő betonoknál felülről közelíti a 3-at.

Vízzáróságra vonatkozóan:

- A vízzárósági vizsgálatok során azt tapasztaltuk, hogy a metakaolin vagy szilikapor adagolás csökkenti a vízbehatolás mértékét.

- Szokványos és öntömörödő betonok esetén a 0,5 alatti víz-cement tényezőnél a vízbehatolás mélysége csekély mértékben változik a v/c csökkenésével. A metakaolin vagy szilikapor adagolásával a vízbehatolás mélységének változása nem észlelhető.

- A mért vízbehatolási mélységek 5 és 30 mm tartomány közé estek.

\section{Köszönetnyilvánítás}

A szerző köszönetet mond az Országos Tudományos Kutatási Alap támogatásáért (OTKA K 109223).

Külön köszönet illetiMogyorósi Zsuzsát, Szántó Juditot, Eipl Andrást, Molnár Pétert és Takács Krisztiánt, a fáradságot és időt nem kímélő laboratóriumi munkájukért. 


\section{Irodalomjegyzék}

(a cikksorozat 1 . és 2 . részére vonatkozóan)

Alshamsi, A. M. - Sabouni, A. R. - Bushlaibi, A. H. (1993): Influence of set-retarding superplasticisers and microsilica on setting times of pastes at various temperatures. Cement and Concrete Research, Vol. 23, No. 3, pp. 592-598. http://dx.doi.org/10.1016/0008-8846(93)90009-X

Asbridge, A. H. - Walters, G. V. - Jones, T. R. (1994): Ternary blended concretes-OPC/ggbs/metakaolin. Proc. Int. Sym. Concrete across borders, Denmark. 1994.

BASF: Tervezési segédlet öntömörödő beton készítéséhez Gleniumª adalékszerekkel. BASF Épitökémia Hungária Kft.

Chandra, S. (1997): Waste Materials Used in Concrete Manufacturing. Noyes Publication, Göteborg. 1997.

chemie.at.

http://www.chemie.at/WebKatalog.aspx?se=category\&id=26. (2015.02.01.)

Elkem. http://www.concrete.elkem.com/dav/38b6b593db.pdf. (2015.02.01.)

Joa, B.-W. - Kima, C.-H. - Taeb, G.-h. - Parka, J.-B. (2007): Characteristics of cement mortar with nano- $\mathrm{SiO}_{2}$ particles. Construction and Building Materials, Vol. 21, No. 6, pp. 1351-1355.

http://dx.doi.org/10.1016/j.conbuildmat.2005.12.020

Jones, T. R. - Walters, G. V. - Kostuch, J. A. (1992): Role of metakaolin in suppressing asr in concrete containing reactive aggregate and exposed to $\mathrm{NaCl}$ solution. Proc. Int. Conf. on AAR, London. 1992.

Justice, J. M. - Kurtis, K. (2007): Influence of Metakaolin Surface Area on Properties of Cement-based Materials. ASCE Journal of Materials in Civil Engineering, Vol. 19, No. 9, pp. 762-771.

http://dx.doi.org/10.1061/(ASCE)0899-1561(2007)19:9(762)

Khayat, K. H. - Aitcin, P. C. (1993): Silica fume: a unique supplementary cementitious material. Mineral Admixtures in Cement and Concrete, Vol. 4.

Kurtis, K. E. (2011): Benefits of Metakaolin in HPC. HPC Bridge Views, Vol. 67.

Larbi, J. A. - Bijen, J. M. (1991): The role of silica fume and metakaolinite in the Portland cement paste-aggregate interfacial zone in relation to the strength of mortars. PhD értekezés, Delft University.

Mehta, P. K. - Monteiro, P. J. M. (2006): Concrete - Microstructure, Properties, and Materials. 3. kiadás. McGraw Hill, USA.

Mindess, S. - Young, J. F. - Darwin, D. (2003): Concrete. Pearson Education, Upper Saddle River, New Jersey. 2003.

Morgan, D. R. - Wolsiefer, J. T. (1991): Silica fume in shotcrete. CANMET/ACI International Workshop on the use of Silica in Concrete, Washington. 1991.

Nehme, S. G. (2004): A beton porozitása. PhD értekezés, BME.

Neville, A. M. (2002): Properties of concrete. 4th Edition. Pearson Education, Harlow, England. 2002.
Newchem. http://catalogue.newchem.org/hungary/Up_files\%5CTDS\%20Metaver\%20N-hu.pdf. (2015.02.01.)

Newman, J. - Choo, B. S. (2003): Advanced Concrete Technology 3 - Processes. Elsevier, Oxford. 2003

Novák, D. - Novák E. (2009): Slagstar 42,5N C3A-mentes új speciális cementfajta az agresszív kémiai korrózió ellen. Vasbetonépités, 2009/3 XI. évfolyam, 3. szám

Pera, J. (2001): Metakaolin and calcined clays, Cement and Concrete Composites, Vol. 23, No. 6, pp. iii http://dx.doi.org/10.1016/S0958-9465(00)00098-6

Poon, C. S. - Lam, L. - Kou, S. C. - Wong, Y. L. - Wong, R. (2001): Rate of pozzolanic reaction of metakaolin in high-performance cement pastes. Cement and Concrete Research, Vol. 31, No. 9, pp. 1301-1306. http://dx.doi.org/10.1016/S0008-8846(01)00581-6

Ramachandran, V. S. (1996): Mineral admixtures. Noyes Publications, USA.

Riesz, L. (1989): Cement- és mészgyártási kézikönyv. Építésügyi Tájékoztatási Központ, Budapest.

Scrivener, K. L. - Nemati, K. M. (1996): The Percolation of Pore Space in the Cement Paste/Aggregate Interfacial Zone of Concrete. Cement and Concrete Research, Vol. 26, No. 1, pp. 35-40. http://dx.doi.org/10.1016/0008-8846(95)00185-9

Siddique, R. - Khan, M. I. (2011): Supplemetary Cementing Materials. Springer - Verlag, Berlin

Siddique, R. (2008): Waste Materials and By-Products in Concrete. Springer Verlag, Berlin.

Sika. http://hucon.webdms.sika.com/fileshow.do?documentID=637. (2015.02.01.)

Sydney_Construction_Materials.

http://www.sydneyconstructionmaterials.com.au/mk_pozzolan.html. (2015.02.01.)

Szilágyi, K. - Borosnyói, A. (2009): 50 years of experience with the Schmidt rebound hammer, Concrete Structures, Vol. 10, pp. 46-56.

Wild, S. - Khatib, J. M. - Jones, A. (1996): Relative strength, pozzolanic activity and cement hydration in superplasticised metakaolin concrete. Cement and Concrete Research, Vol. 26, No. 10, pp. 1537-1544.

http://dx.doi.org/10.1016/0008-8846(96)00148-2

Ref.

Nehme, Salem G.: Kiegészitöanyagok hatása a szokványos és az öntömörödö betonokra.

2. rész. Laboratóriumi vizsgálatok

Építỏanyag - Journal of Silicate Based and Composite Materials,

Vol. 67, No. 2 (2015), 71-78. p.

http://dx.doi.org/10.14382/epitoanyag-jsbcm.2015.12

\section{〔CHEMEUROPE.COM}

\section{Topic Overview}

On the chemie.de topic pages you find science and product information, news, facts and backgrounds on techniques, products, disciplines, companies, chemicals, and other topics regarding chemistry, analytics and chemical engineering. The dossiers offer you fast and easy access to different subjects and combine basic and specific information, trends and development in a comprehensive overview.

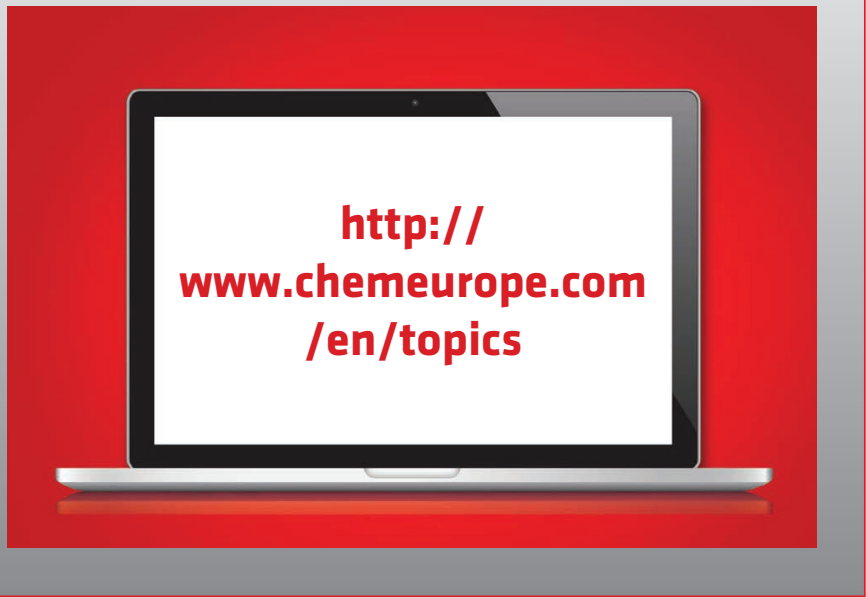

